\title{
Outpatient treatment of perianal warts by scissor excision
}

\author{
A McMILLAN AND G R SCOTT \\ From the University Department of Genitourinary Medicine, Royal Infirmary, Edinburgh
}

SUMMARY A method of scissor excision of perianal warts, which is suitable for use in outpatient departments, is described. The low recurrence rate (two of 24 patients) three months after treatment is encouraging.

\section{Introduction}

The number of patients who present to departments of genitourinary medicine, and in whom a diagnosis of anogenital warts is made, is increasing. Perianal or anal warts, which are found in about one third of patients with genital warts ${ }^{1}$ are particularly troublesome as they are often extensive, bleed easily, interfere with normal hygiene, and often become secondarily infected.

The results of topical treatment of anogenital warts with podophyllin, either alone or combined with trichloracetic acid, are disappointing, as only about one fifth of patients have no visible wart tissue after three months of applications once a week. ${ }^{2}$ Though cryotherapy and electrocautery have proved useful, multiple treatments, particularly with cryotherapy, are usually required. ${ }^{3}$ Pain after the electrocautery of multiple warts can be distressing, and anal stenosis is a risk after removal of extensive lesions by diathermy.

Scissor excision of perianal and anal warts has been described by Thomson. ${ }^{4}$ The major advantage of this method is that only abnormal tissue is removed, with little damage to the surrounding tissue. Of 28 patients treated by this method, $20(71 \%)$ were classed as primary cures in the series reported by Gollock et al. ${ }^{5}$ This procedure, however, involves the subcutaneous or submucous injection of $20-150 \mathrm{ml}$ of saline and, as a general or caudal anaesthetic is required, is unsuitable for use in outpatient departments. We have assessed a

Address for reprints: Dr A McMillan, Department of Genitourinary Medicine, Royal Infirmary, Lauriston Place, Edinburgh EH3 9YW

Accepted for publication 6 June 1986 method of scissor excision that can be used in the outpatient department.

\section{Patients and methods}

Scissor excision of perianal warts was undertaken on 51 patients ( 40 men, 27 of whom had had homosexual contact, and 11 women) who attended consecutively this department between 1 March and 31 December 1985 and who: (in the case of women) were not pregnant; had no known abnormality of their clotting system; did not have chronic liver disease; were not known to be hypersensitive to lignocaine, had warts whose bases were $3 \mathrm{~mm}$ or more and less than $1 \mathrm{~cm}$ in diameter, and did not have warts within the anal canal. The median duration of the warts was 3.2 months (range two weeks to four years).

After a careful physical examination and the collection of the appropriate material for microbiological examination for sexually transmitted infections, ${ }^{6}$ scissor excision of warts was performed as follows. Patients were positioned in the left lateral position, on a standard operating table covered with absorbent towels. After cleansing the perianal region, the skin around the base of the warts was infiltrated with lignocaine $1 \%(\mathrm{w} / \mathrm{v})$ containing adrenaline at a final dilution of 1:200000. The volume of lignocaine varied from $2 \mathrm{ml}$ to $10 \mathrm{ml}$, depending on the size and number of warts. The wart was excised using fine pointed curved scissors and toothed dissecting forceps. On average, the elliptical wound was $3 \mathrm{~mm}$ long. On two occasions, the wound was sufficiently long (about 1 $\mathrm{cm}$ ) to necessitate the use of an under-running chromic catgut suture. The area was dressed with sterile swabs, and patients were rested for about 30 minutes before 
being allowed home.

Patients were asked to change the dressings three times a day for two to three days. Paracetamol tablets were supplied, and patients instructed to take $1 \mathrm{~g}$ every six hours as required for the control of perianal discomfort. Regular bowel habit was encouraged by the use of a high fibre diet. Homosexual men were asked to refrain from anal intercourse for at least 10 days.

After use, the paper towelling and soiled swabs were carefully collected in bags, which were then sealed and destroyed by incineration. The surface of the table was washed with activated glutaraldehyde solution (Cidex). Scissor excisions were performed at the end of the clinic so that the table could be left for at least 12 hours after use. Used instruments were left overnight in Cidex before being washed and packaged for autoclaving.

Patients were invited to attend the department 1, 2, 4,8 , and 12 weeks later. Any small external warts were treated by podophyllin $25 \%(\mathrm{w} / \mathrm{v})$ in industrial methylated spirit.

\section{Results}

Though there was no recurrence of warts at the sites of scissor excision, new but small (less than $3 \mathrm{~mm}$ in diameter) lesions were noted in six of the 34 patients who were reviewed one month after treatment. In each case, these small lesions resolved after treatment with, at most, three applications of podophyllin at weekly intervals. Recurrence was noted in only two of the 24 patients who attended for the three month follow up examination.

In all but one patient, who had pronounced perianal discomfort and required pentazocine as analgesic, pain after excision was mild and easily controlled with paracetamol. Appreciable postoperative bleeding was not encountered.

\section{Discussion}

Though the number of patients studied was small, the low recurrence rate after three months was encouraging. Simmons noted that only $22 \%$ of 109 men whose anogenital warts had been treated with podophyllin were free of lesions at three months. ${ }^{7}$ Overall, those 109 patients had required a mean of 10.7 weekly applications. Better results were reported on the use of cryotherapy and electrocautery, ${ }^{3}$ the cure rates at three months being $42 \%$ of 24 and $56 \%$ of 18 men, respectively. Intense discomfort had been reported after cryotherapy, however, and the burns produced by electrocautery can be painful. With one exception, our patients reported little discomfort, which was easily controlled by one to three doses of paracetamol.

Our findings are similar to those of Jensen, ${ }^{8}$ who compared simple scissor excision with topical podophyllin and found that 28 of 30 patients treated surgically were cured. Four of his patients, however, reported severe pain after the procedure, but this may have been related to the size of the lesions. We limited this method of treatment to warts that were less than $1 \mathrm{~cm}$ in diameter, and referred patients with larger warts to our surgical colleagues for excision under general anaesthesia. Small flat warts $(3 \mathrm{~mm}$ or less in diameter) are difficult to excise, and surgical treatment of these was not attempted; in most cases these responded to podophyllin after excision of the larger warts.

An advantage of scissor excision is that the lesions can be examined histologically. With the increasing recognition of premalignant and malignant disease of the anorectum in homosexual men, ${ }^{9}$ this may be important.

Though bleeding during excision is minimal, great care should be taken to prevent transmission of infection, including hepatitis B virus and human immunodeficiency virus. As the operating table required disinfection after use, the number of patients whose warts can be dealt with by scissor excision in busy outpatient departments may be limited.

\section{References}

1. Oriel JD. Anal warts and anal coitus. British Journal of Venereal Diseases 1971;47:373-6.

2. Gabriel G, Thin RNT. Treatment of anogenital warts. Comparison of trichloracetic acid and podophyllin versus podophyllin alone. British Journal of Venereal Diseases 1983;59:124-6.

3. Simmons PD, Langlet F, Thin RNT. Cryotherapy versus electrocautery in the treatment of genital warts. British Journal of Venereal Diseases 1983;57:273-4.

4. Thomson JPS. Perianal and anal condylomata accuminata. In: Smith R, Rob C, eds. Operative surgery. Colon, rectum and anus. London: Butterworths, 1977:376-8.

5. Gollock JM, Slatford K, Hunter JM. Scissor excision of anogenital warts. British Journal of Venereal Diseases 1982;58:400-1.

6. McMillan A, Lee FD. Sigmoidoscopic and microscopic appearance of the rectal mucosa in homosexual men. Gut 1981;22:1035-41.

7. Simmons PD. Podophyllin $10 \%$ and $25 \%$ in the treatment of anogenital warts: a comparative double blind study. British Journal of Venereal Diseases 1981;57:208-9.

8. Jensen SL. Comparison of podophyllin application with single surgical excision in clearance and recurrence of condylomata acuminata. Lancet 1985; ii:1126-8.

9. Croxson T, Chabon AB, Rorat E, Barash IM, Intraepithelial carcinoma of the anus in homosexual men. Dis Colon Rectum 1984;27:325-30. 